Fifth International Conference on Sustainable Construction Materials and

Technologies. http://www.claisse.info/Proceedings.htm

\title{
RECYCLING OF CONCRETE MADE WITH BRICK AGGREGATE: AN EXTENDED STUDY
}

\author{
Tarek U. Mohammed ${ }^{1}$, Kazi I. Hossain ${ }^{1}$, Mohidul I. Anik ${ }^{1}$, Imtiaz H. Miraz ${ }^{1}$, \\ Tanvir Ahmed ${ }^{1}$, and Mohammed A. Awal' \\ ${ }^{1}$ Department of Civil and Environmental Engineering, Islamic University of \\ Technology (IUT), Organisation of Islamic Cooperation (OIC), Board Bazar, \\ Gazipur-1704, Bangladesh.E-mail: 〈tarek@iut-dhaka.edu>, \\ <kaziismi@gmail.com>, <mohidanik41@gmail.com>, <imtiazmiraz@gmail.com>, \\ <tanvirbd@iut-dhaka.edu>. \\ ${ }^{2}$ Managing Director, SEL Center, 29 Bir Uttam Kazi Nuruzzaman Sarak, West \\ Panthapath, Dhaka 1205. Email:〈a.awal05@yahoo.com>.
}

\begin{abstract}
An extended study was carried out to explore the possibility of recycling of concrete made with brick aggregate as coarse aggregate. Demolished concrete blocks were collected from six demolished building sites and then crushed into coarse aggregate manually. Physical properties of the coarse aggregate collected from the blocks were evaluated. Cylindrical concrete samples $(100 \mathrm{~mm}$ by $200 \mathrm{~mm})$ were made using recycled aggregates with $\mathrm{W} / \mathrm{C}=0.40,0.45$ and 0.50 . The specimens were tested for compressive strength, tensile strength, and Young's modulus of concrete at the ages of 7,14 , and 28 days. Control specimens were also made using virgin brick aggregate to compare with the results of recycled aggregate. The experimental results revealed that recycled brick aggregates have lower absorption capacity compared to the virgin brick aggregate. The average strength of concrete made with recycled brick aggregate was found to be $29 \mathrm{MPa}$ and $23.5 \mathrm{MPa}$ for $\mathrm{W} / \mathrm{C}=0.45$ and 0.55 respectively.
\end{abstract}

Keywords: Recycled brick aggregate, coarse aggregate, compressive strength, tensile strength, young modulus.

\section{INTRODUCTION}

Concrete consumption in the world is estimated at two tons per capita per year (equivalent to 12 billion tons) [Mehta 2002]. To make this huge volume of concrete 1.5 billion tons of cement, 9.3 billion tons of aggregate, 1.2 billion tons of water are necessary. Also, about 1.5 billion tons of steel is necessary. Generally, aggregates are 
collected by cutting mountains or breaking river gravels or boulders, or by breaking clay bricks. A significant amount of natural resource can be saved if the demolished concrete is recycled for new constructions. In addition to the saving of natural resources, recycling of demolished concrete will also provide other benefits, such as creation of additional business opportunities, saving cost of disposal, saving money for local government and other purchaser, helping local government to meet the goal of reducing disposal, etc. At present, the amount of global demolished concrete is estimated at 2 3 billion tons [Torring and Lauritzen 2002]. Sixty to seventy percent of demolished concrete is used as sub-base aggregate for road construction [Yanagibashi et al 2002]. By recycling of demolished concrete, $30 \%$ of normal aggregates can be saved. It is also estimated that in the next ten years, the amount of demolished concrete will be increased to 7.5 12.5 billion tons [Torring and Lauritzen 2002]. If technology and public acceptance of using recycled aggregate are developed, there will be no requirement for normal aggregate if $100 \%$ of demolished concrete is recycled for new construction. However, it the responsibility of researchers to make a strong platform for recycling of demolished concrete based on the world-wide extensive research works.

In Bangladesh, the volume of demolished concrete is increasing due to the deterioration of concrete structures as well as the replacement of many low-rise buildings by relatively high-rise buildings due to the booming of real estate business. Therefore, disposal of the demolished concrete is becoming a great concern to the developers of the buildings as well as to the environment. If the demolished concrete is used for new construction, the disposal problem will be solved, the demand for new aggregates will be reduced, and finally consumption of the natural resources for making aggregate will be reduced. In some project sites, it was also found that a portion of the demolished concrete is used as aggregate in foundation works without any research on the recycled aggregates. In most of the old buildings, brick chips were used as coarse aggregate of concrete. Studies related to the recycling of demolished concrete are generally found for stone chips made concrete [Alan 1977, and Gomez-Soberon et al 2002]. Therefore, investigations on recycling of brick made demolished concrete are strongly necessary. With this background, this study was planned since 2004 with an objective of sustainable development of construction materials in Bangladesh [Mohammed 2007]. Demolished concrete blocks were collected from 33 demolished building sites of various ages and investigated for physical and mechanical properties of concrete. The results revealed that demolished concrete blocks can be recycled as coarse aggregate for utilization in structural concrete [Mohammed et al 2015]. For making a complete and accurate guideline for recycling of demolished concrete, it was decided to extend this study to 17 additional demolished building sites. Therefore, as an extended study, demolished concrete blocks were collected from six different demolished building sites for further investigation. The results related to these sites are summarized here. A complete report summarizing the results of recycled brick aggregate collected from 50 different building sites will be prepared by 2020 . 


\section{EXPERIMENTAL METHOD}

Demolished concrete blocks were collected from the structural members of the demolished buildings. The collected concrete samples were broken into pieces manually in three particular sizes as $25 \mathrm{~mm}$ to $20 \mathrm{~mm}, 20 \mathrm{~mm}$ to $10 \mathrm{~mm}$, and $10 \mathrm{~mm}$ to $5 \mathrm{~mm}$. Demolished concrete blocks and recycled aggregates are shown in Figure 1. After breaking into pieces, the aggregates were mixed as $5 \%$ from $25 \mathrm{~mm}$ to $20 \mathrm{~mm}$, $57.5 \%$ from $20 \mathrm{~mm}$ to $10 \mathrm{~mm}$, and $37.5 \%$ from $10 \mathrm{~mm}$ to $5 \mathrm{~mm}$ as per ASTM C33-93. The aggregates were tested for absorption capacity, specific gravity, unit weight, and abrasion. The specific gravity and absorption capacity are determined as per ASTM C128, unit weight as per ASTM C29, and abrasion value as per ASTM C131. As a control case, first class brick aggregates were used. The fineness modulus (FM), water absorption and specific gravity of sand used in this investigation were $2.64,3.9 \%$, and 2.61 , respectively. Normal tap water was used as mixing water. The temperature of the mixing water was about $20^{\circ} \mathrm{C}$. Saturated surface dry (SSD) sand and aggregate were used for making concrete.

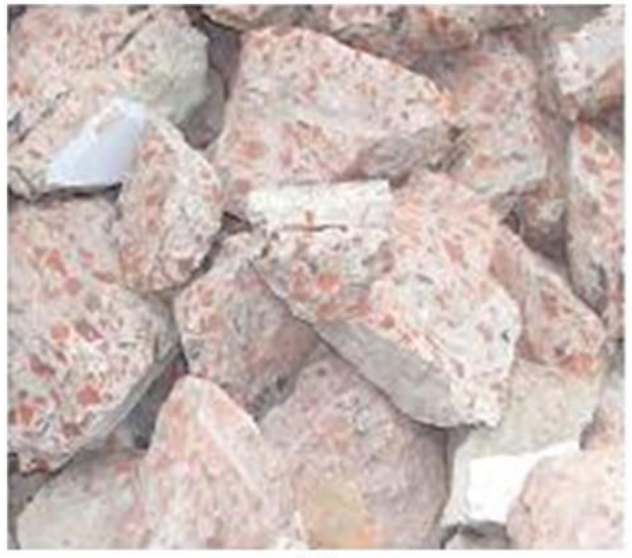

(a)

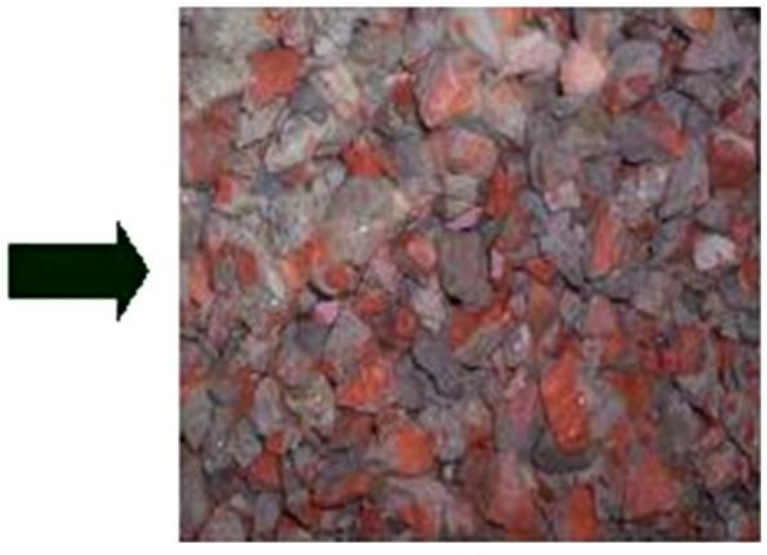

(b)

Figure 1. (a) Demolished Concrete Block, and (b) Recycled Brick Coarse Aggregate

Table 1: Cases Investigated (16 Cases)

\begin{tabular}{|l|c|c|c|c|}
\hline Cases & \multicolumn{4}{|c|}{ Parameters } \\
\hline & $\begin{array}{c}\text { Type of } \\
\text { Aggregate }\end{array}$ & $\begin{array}{c}\text { Age } \\
(\text { Years })\end{array}$ & W/C & $\begin{array}{c}\text { Cement Content } \\
\left(\mathrm{kg} / \mathrm{m}^{3}\right)\end{array}$ \\
\hline FB-45 & BA & - & 0.55 & 340 \\
\hline FB-55 & BA & - & 0.45 & 340 \\
\hline RBY20-45 & RBA & 20 & 0.45 & 340 \\
\hline RBY20-55 & RBA & 20 & 0.55 & 340 \\
\hline RBY43-45 & RBA & 43 & 0.45 & 340 \\
\hline RBY43-55 & RBA & 43 & 0.55 & 340 \\
\hline RBY8-45 & RBA & 8 & 0.45 & 340 \\
\hline
\end{tabular}




\begin{tabular}{|l|c|c|c|c|}
\hline RBY8-55 & RBA & 8 & 0.55 & 340 \\
\hline RBY18-45 & RBA & 18 & 0.45 & 340 \\
\hline RBY18-55 & RBA & 18 & 0.55 & 340 \\
\hline RBY37-45 & RBA & 37 & 0.45 & 340 \\
\hline RBY37-55 & RBA & 37 & 0.55 & 340 \\
\hline RBY25-45 & RBA & 25 & 0.45 & 340 \\
\hline RBY25-55 & RBA & 25 & 0.55 & 340 \\
\hline $\begin{array}{l}\text { RBY25-40- } \\
400\end{array}$ & RBA & 25 & 0.45 & 400 \\
\hline $\begin{array}{l}\text { RBY25-40- } \\
450\end{array}$ & RBA & 25 & 0.55 & 450 \\
\hline
\end{tabular}

BA - Brick aggregate, RBA - Recycled brick aggregate

Table 2: Mixture Proportions of Concrete (16 Cases)

\begin{tabular}{|c|c|c|c|c|c|c|c|}
\hline \multirow[b]{2}{*}{ Cases } & \multirow[b]{2}{*}{$\mathrm{W} / \mathrm{C}$} & \multirow[b]{2}{*}{ s/a } & \multicolumn{4}{|c|}{ Unit Contents $\left(\mathrm{kg} / \mathrm{m}^{3}\right)$} & \multirow[b]{2}{*}{$\begin{array}{l}\text { Admixtu } \\
\text { re }\left(\mathrm{L} / \mathrm{m}^{3}\right)\end{array}$} \\
\hline & & & Cement & $\begin{array}{c}\text { Fine } \\
\text { Aggregate }\end{array}$ & $\begin{array}{c}\text { Coarse } \\
\text { Aggreg } \\
\text { ate }\end{array}$ & Water & \\
\hline FB-45 & 0.45 & 0.44 & 340 & 827 & 884 & 153 & 3.06 \\
\hline FB-55 & 0.55 & 0.44 & 340 & 761 & 843 & 187 & 0.00 \\
\hline RBY20-45 & 0.45 & 0.44 & 340 & 798 & 884 & 153 & 3.06 \\
\hline RBY20 -55 & 0.55 & 0.44 & 340 & 761 & 843 & 187 & 0.00 \\
\hline RBY43-45 & 0.45 & 0.44 & 340 & 798 & 867 & 153 & 3.06 \\
\hline RBY43 -55 & 0.55 & 0.44 & 340 & 761 & 827 & 187 & 0.00 \\
\hline RBY8 -45 & 0.45 & 0.44 & 340 & 798 & 846 & 153 & 3.06 \\
\hline RBY8-55 & 0.55 & 0.44 & 340 & 761 & 807 & 187 & 0.00 \\
\hline RBY18 -45 & 0.45 & 0.44 & 340 & 818 & 833 & 153 & 3.06 \\
\hline RBY18 -55 & 0.55 & 0.44 & 340 & 779 & 793 & 187 & 0.00 \\
\hline RBY37 -45 & 0.45 & 0.44 & 340 & 818 & 833 & 153 & 3.06 \\
\hline RBY37 -55 & 0.55 & 0.44 & 340 & 779 & 793 & 187 & 0.00 \\
\hline RBY25 -45 & 0.45 & 0.44 & 340 & 818 & 825 & 153 & 3.06 \\
\hline RBY25 -55 & 0.55 & 0.44 & 340 & 779 & 785 & 187 & 0.00 \\
\hline $\begin{array}{l}\text { RBY25-40- } \\
400\end{array}$ & 0.40 & 0.44 & 400 & 788 & 794 & 160 & 3.06 \\
\hline $\begin{array}{l}\text { RBY25-40- } \\
450\end{array}$ & 0.40 & 0.44 & 450 & 746 & 753 & 180 & 3.06 \\
\hline
\end{tabular}

Table 3: Properties of Aggregate Investigated

\begin{tabular}{|c|c|c|c|c|}
\hline Type & $\begin{array}{c}\text { Age } \\
\text { (Years) }\end{array}$ & $\begin{array}{c}\text { Specific } \\
\text { Gravity }\end{array}$ & $\begin{array}{c}\text { Absorption } \\
\text { Capacity } \\
(\%)\end{array}$ & $\begin{array}{c}\text { Abrasion } \\
(\%)\end{array}$ \\
\hline
\end{tabular}




\begin{tabular}{|c|c|c|c|c|}
\hline FB & - & 2.20 & 17.12 & 39 \\
\hline RBY20 & 20 & 2.14 & 13.06 & 48 \\
\hline RBY43 & 43 & 2.1 & 13.72 & 49 \\
\hline RBY08 & 08 & 2.05 & 14.72 & 48 \\
\hline RBY18 & 18 & 2.08 & 13.08 & 48 \\
\hline RBY37 & 37 & 2.08 & 13.76 & 48 \\
\hline RBY25 & 25 & 2.07 & 15.91 & 50 \\
\hline
\end{tabular}

After investigation of aggregates, concrete cylinders of size $100 \mathrm{~mm}$ in diameter and $200 \mathrm{~mm}$ in height were made for evaluation of compressive strength at 7, 14, and 28 days as per ASTM C39. The investigated cases are summarized in Table 1. The mixture proportions of concrete for all cases are summarized in Table 2. Sixteen cases were investigated. W/C ratios of concrete were $0.40,0.45$ and 0.55 . Cement content of concrete was $340 \mathrm{~kg} / \mathrm{m}^{3}$. For some cases, it was increased to $400 \mathrm{~kg} / \mathrm{m}^{3}$ and $450 \mathrm{~kg} / \mathrm{m}^{3}$. Sand to total aggregate volume ratio was 0.44 . Naphthalene based superplasticizer was used for $\mathrm{W} / \mathrm{C}=0.45$ to improve the workability of concrete. Total mixing time of concrete was controlled at 5.5 minutes. After mixing concrete, the workability of concrete was measured by slump cone test. Cylinder concrete specimens were made and demolded after one day of casting. Then the specimens were cured under wet jute bags continuously. The compressive strength of concrete was measured at 7,14 , and 28 days by using Universal Testing Machine (UTM). The strain of concrete specimens was measured by a strain measurement setup with two dial gauges. The gauge length was $100 \mathrm{~mm}$. The failure surfaces of concrete were also checked carefully after crushing of the concrete cylinders. The Young's modulus of concrete was determined from the stress-strain curves. The stress of concrete at strain level 0.0005 was used to determine the Young's modulus of concrete. Ultrasonic Pulse Velocity (UPV) through concrete was also measured before crushing of the specimens for compressive strength. A total 192 concrete cylinders was investigated for 16 cases as summarized in Table 1.

\section{RESULTS AND DISCUSSION}

\section{Properties of Aggregate}

The properties of recycled brick aggregates collected from three demolished building sites are summarized in Table 3 . The ages of the aggregates were $8,18,20,25,37$, and 43 years. The absorption capacity of the recycled aggregates is lower than the first class brick aggregate. The abrasion value of recycled brick aggregate is higher than the virgin brick aggregate, however the abrasion value is lower than the maximum value specified in ASTM C33. From these data, it is understood that recycled brick aggregate is better or similar compared to the first class brick aggregate commonly used in Bangladesh. Similar results were observed in a separate extensive study conducted on recycled aggregate collected from 33 different building sites [Mohammed et al 2015]. 


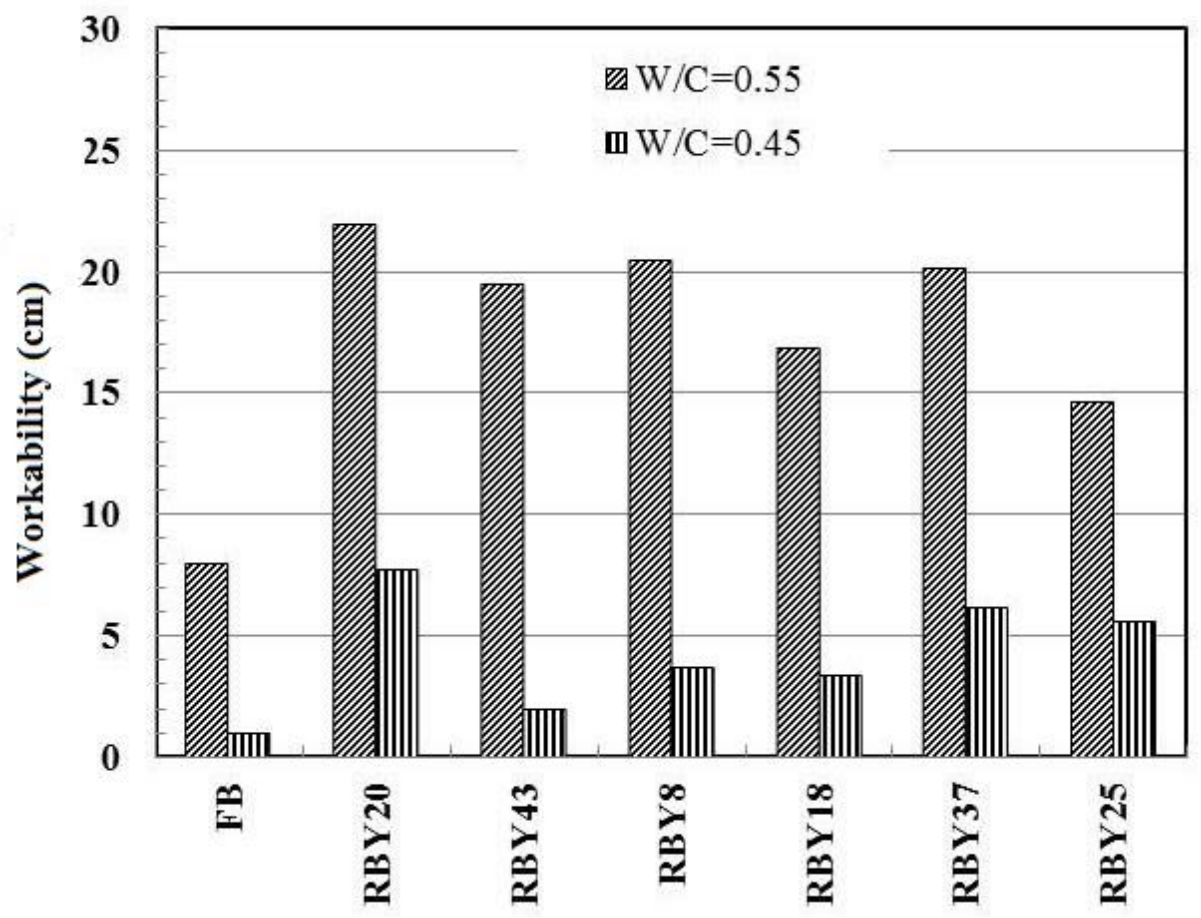

Fig. 2. Workability of Concrete (W/C $=0.55$ and $\mathrm{W} / \mathrm{C}=0.45$ ) 

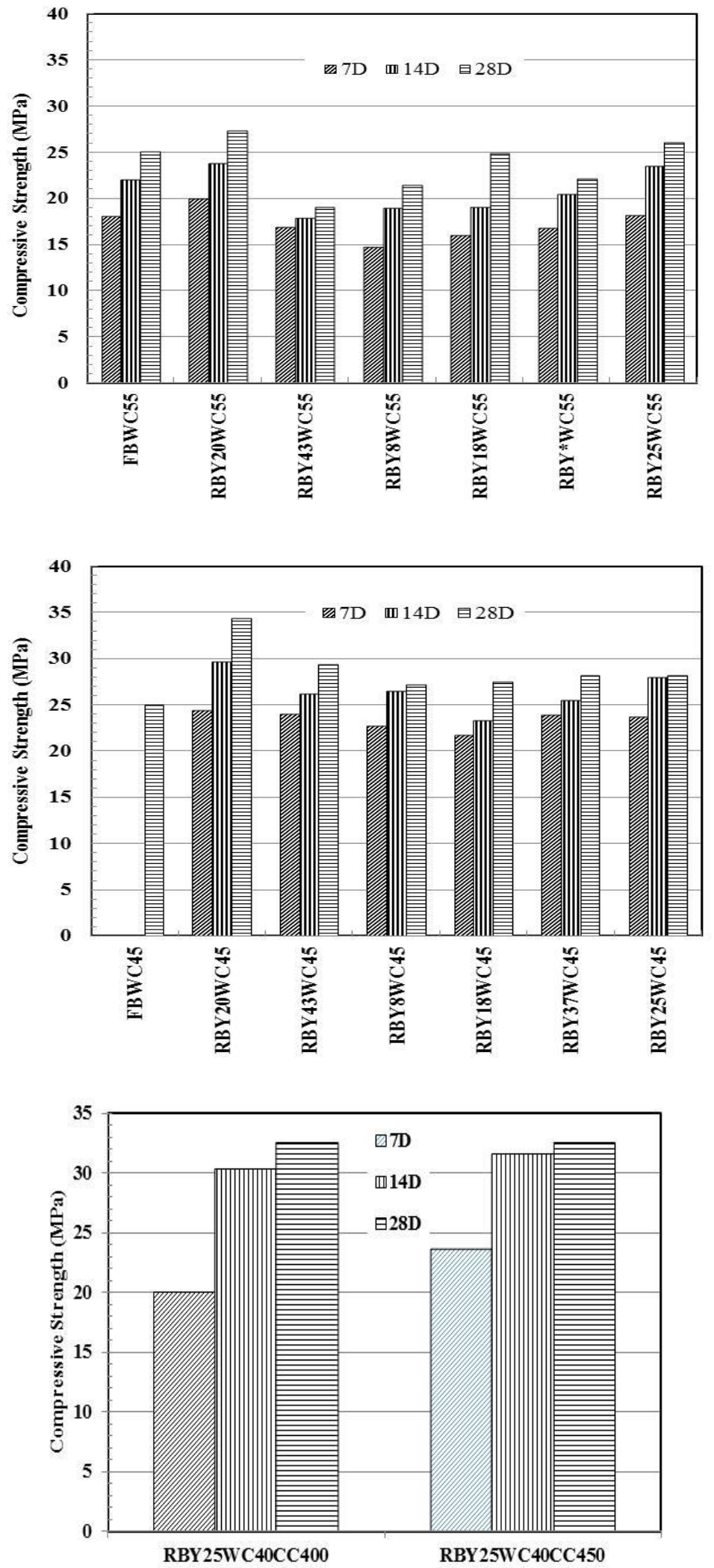

Fig. 3. Compressive Strength of Concrete 

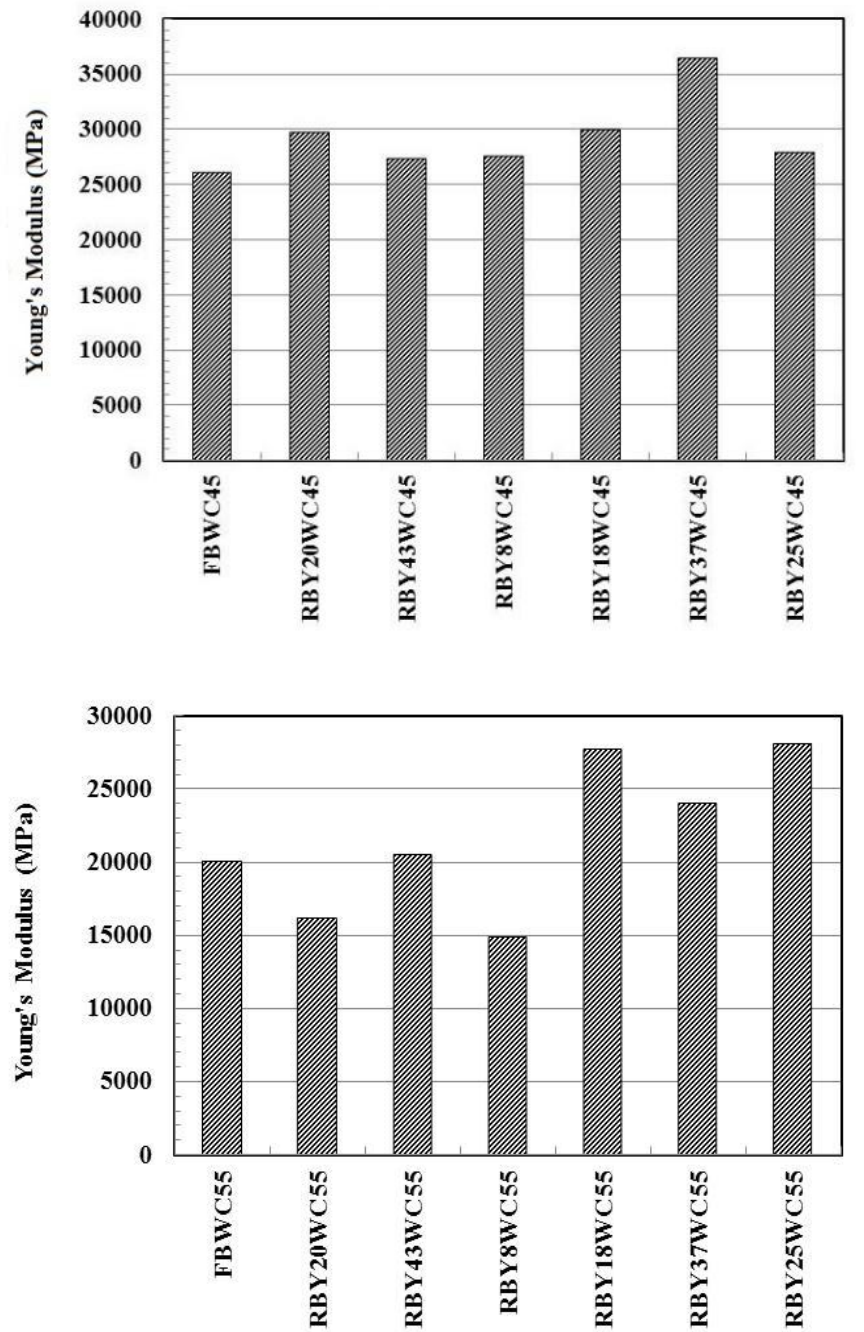

Fig. 4. Young's Modulus of Concrete 


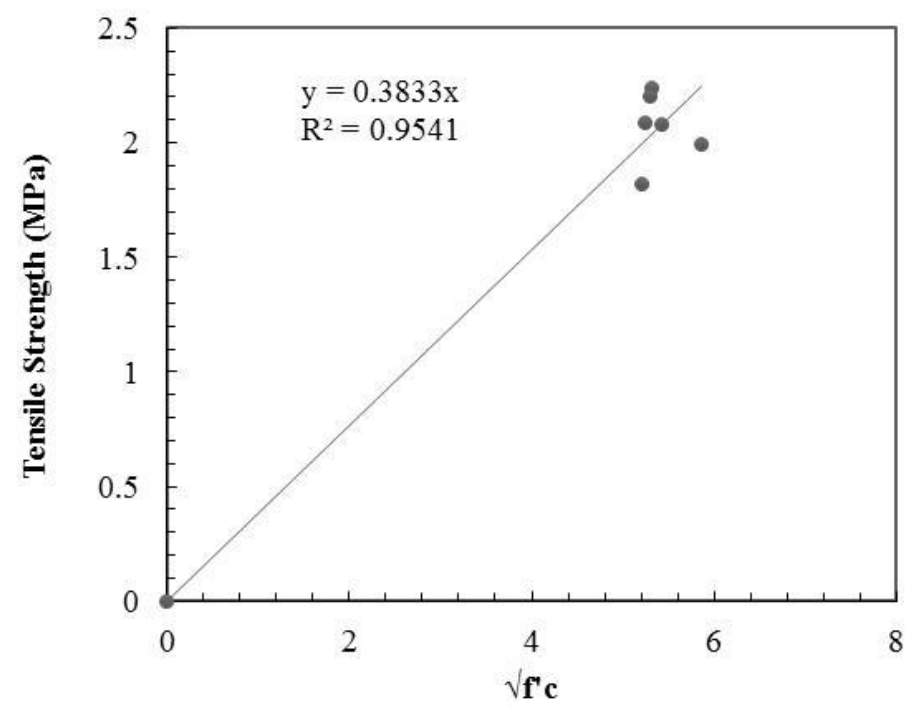

Fig. 5. Relationship between Tensile Strength and Compressive Strength of Concrete

\section{Workability of Concrete}

The workability of concrete as slump (in $\mathrm{cm}$ ) is shown in Figure 2 for $\mathrm{W} / \mathrm{C}=0.55$ and 0.45 . For, $\mathrm{W} / \mathrm{C}=0.45$ naphthalene based high range water reducing chemical admixture was used to improve workability of concrete. For $\mathrm{W} / \mathrm{C}=0.55$ and $\mathrm{W} / \mathrm{C}=0.45$, it is found that workability of the recycled brick aggregate concrete is higher compared to the first class brick aggregate concrete (FB). It is expected due to the angular shape of the brick aggregate. On the other hand, the corner faces of the recycled brick aggregate were relatively blunt due to the adhered old mortar. Similar observation was also found in another study (Mohammed et al 2015).

\section{Compressive Strength of Concrete}

The compressive strength of concrete at 7,14 and 28 days is shown in Figure 3. For $\mathrm{W} / \mathrm{C}=0.55$, in most of the cases a lower value of strength of concrete is found for recycled brick aggregate concrete compared to the first class brick aggregate concrete (FBWC55). However, for $\mathrm{W} / \mathrm{C}=0.45$, the compressive strength of recycled aggregate concrete is higher than the first class brick aggregate concrete (FBWC45). The results indicate that for a low $\mathrm{W} / \mathrm{C}$, recycled brick aggregates show better performance compared to a high W/C with respect to compressive strength of concrete. It indicates that for possible recycling of demolished concrete block as coarse aggregate, it is necessary to reduce W/C. Similar observation was also found in another study (Mohammed et al 2015).

An attempt was made to increase compressive strength of concrete by reducing $\mathrm{W} / \mathrm{C}$ to 0.40 and increasing cement content to $400 \mathrm{~kg} / \mathrm{m}^{3}$ and $450 \mathrm{~kg} / \mathrm{m}^{3}$ from $340 \mathrm{~kg} / \mathrm{m}^{3}$. These results are also shown in Figure 3. It is found that compressive strength of recycled 
aggregates concrete is increased to $32 \mathrm{MPa}$ due to the addition of more cement and reduction of $\mathrm{W} / \mathrm{C}$.

\section{Young's Modulus of Concrete}

Young's modulus of concrete at 28 days for different cases is shown in Figure 4. For $\mathrm{W} / \mathrm{C}=0.55$, recycled brick aggregate shows lower Young's modulus compared to the virgin brick aggregate concrete. However, for $\mathrm{W} / \mathrm{C}=0.45$, it found that Young's modulus of demolished brick aggregate concreter is higher than the brick aggregate concrete. Similar variation also observed in the compressive strength of concrete. Reduction of W/C of recycled aggregate concrete improves Young's modulus of concrete.

\section{Relationship between Tensile Strength and Compressive Strength}

The variation of tensile strength with the variation of square root of compressive strength of concrete is shown in Figure 5. The following linear relationship between tensile strength, $f_{t}(\mathrm{MPa})$ and square root of compressive strength, $f_{c}^{\prime}(\mathrm{MPa})$ of concrete is proposed.

$$
f_{t}=0.3833 \sqrt{f_{c}^{\prime}}
$$

The slope of the proposed line is found to be 0.5 in another extensive study on recycled brick aggregate (Mohammed et al 2015).

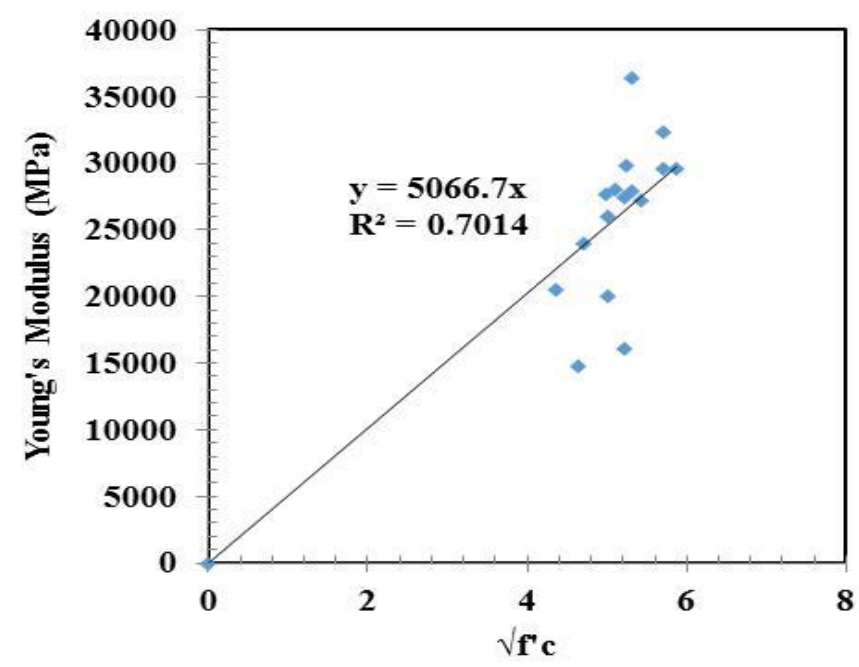

Fig. 6. Relationship between Young's Modulus and Compressive Strength of Concrete 


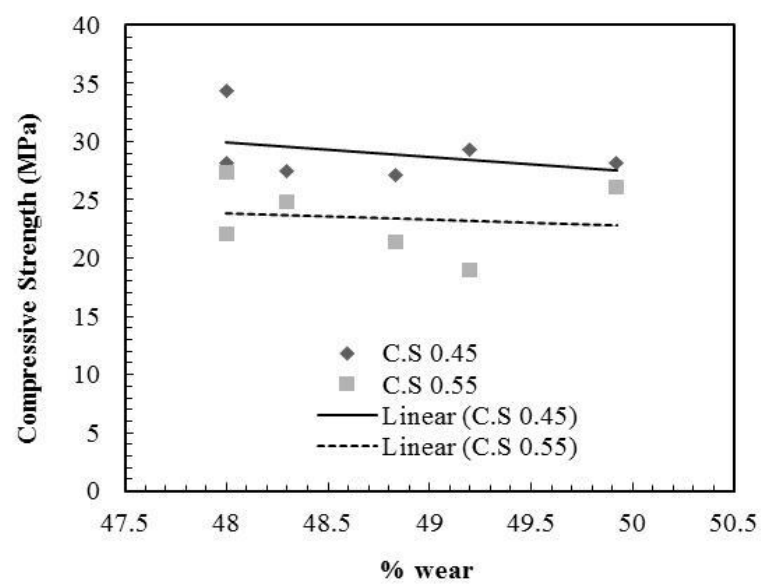

Fig. 7. Relationship between Compressive Strength and Wear of Recycled Aggregate

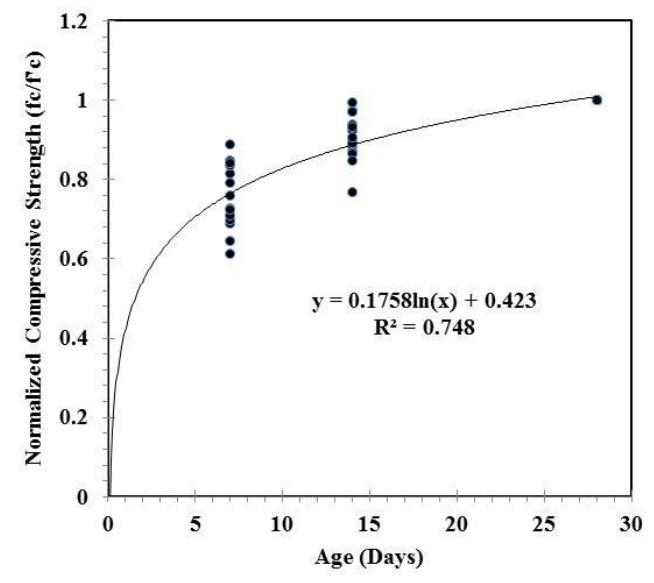

Fig. 8. Variation of Normalized Strength with Time 


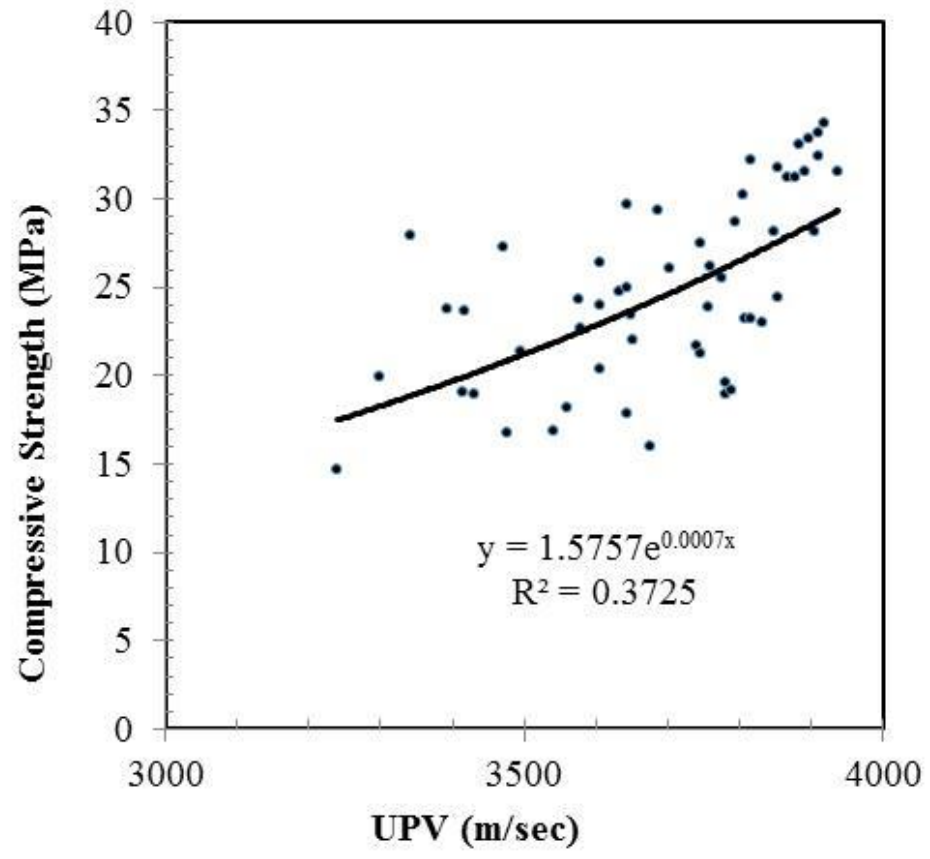

Fig. 9. Variation of Compressive Strength with UPV

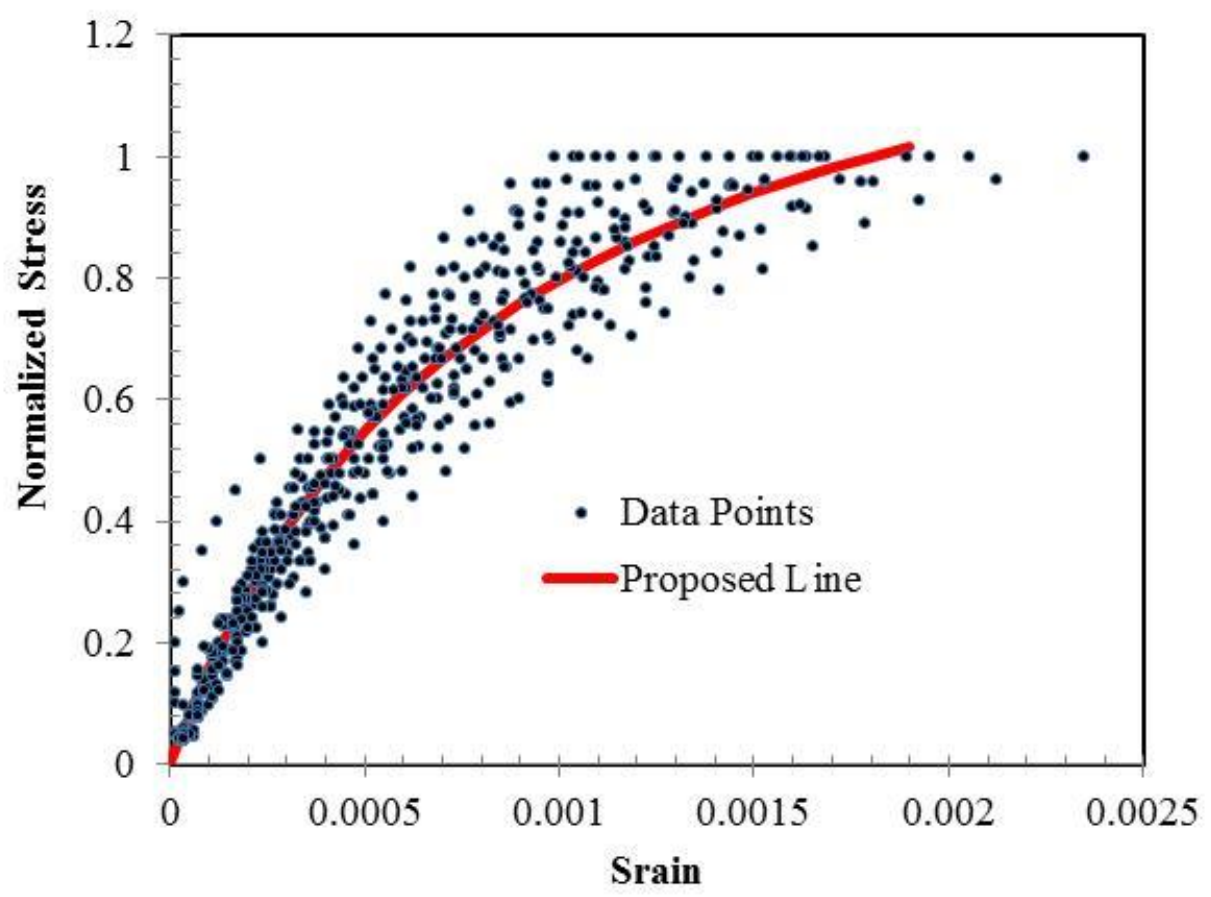

Fig. 10. Stress-Strain Curve of Concrete 

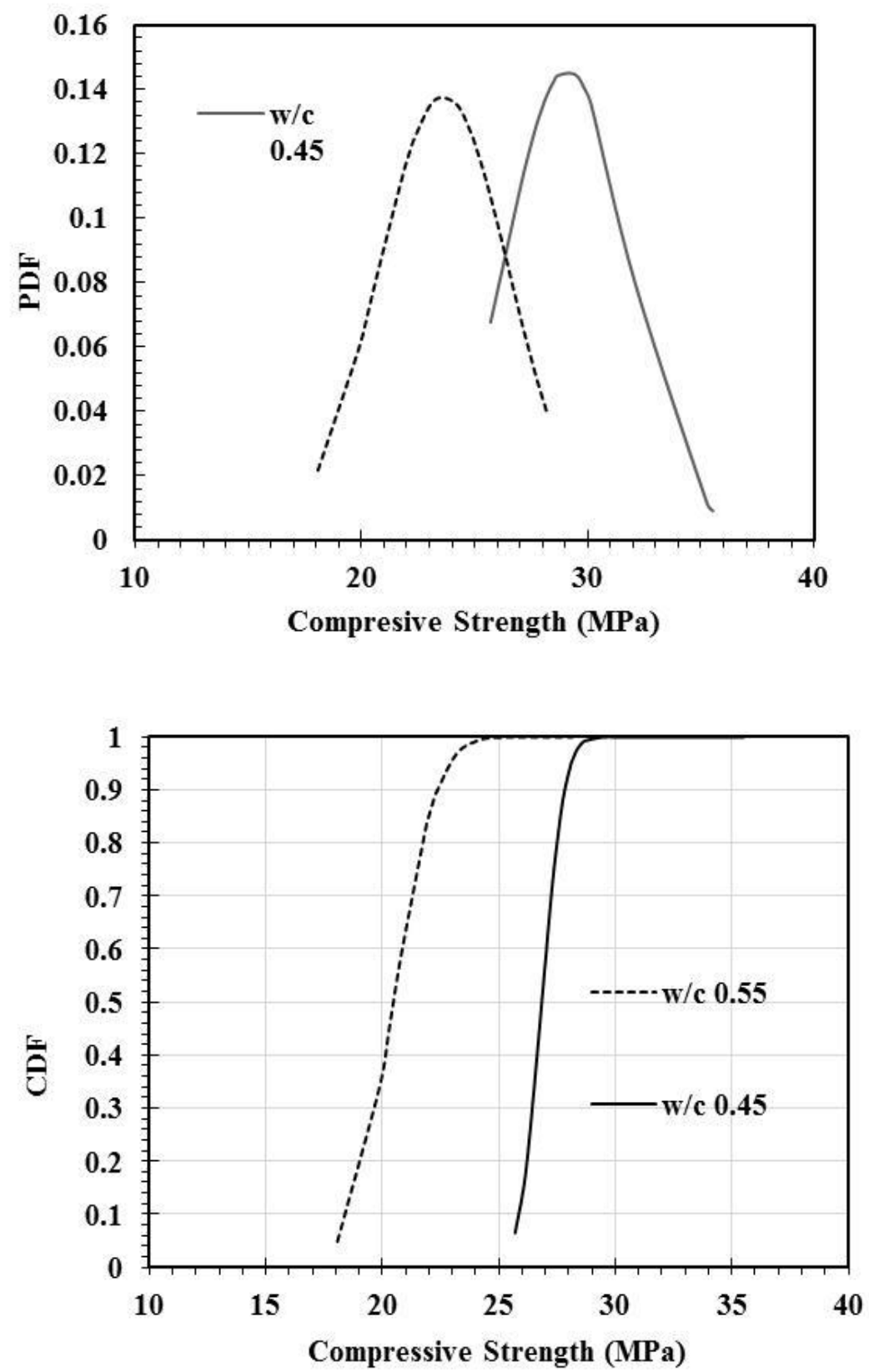

Fig. 11. PDF and CDF of Compressive Strength of Concrete (W/C $=0.55$ and $\mathrm{W} / \mathrm{C}=0.45)$

\section{Relationship between Young's Modulus and Compressive Strength}

The variation of Young's modulus and square root of compressive strength of concrete is shown in Figure 6. The following linear relationship between Young's modulus, $E_{c}$ (MPa) and square root of compressive strength, $f_{c}^{\prime}$ (MPa) of concrete is proposed. 


$$
E_{c}=5067 \sqrt{f_{c}^{\prime}}
$$

The slope of the proposed line is found to be 3595 in another extensive study conducted on recycled brick aggregate (Mohammed et al 2015).

\section{Relationship between Compressive Strength and Wear of Aggregate}

The variation of compressive strength of concrete with the variation of wear value of recycled aggregate is shown in Figure 7. It is found that irrespective of W/C, the compressive strength of concrete is reduced with the increase of the wear value. Similar trend of results was also reported in another study [Mohammed et al 2015].

\section{Strength versus Time Relationship}

The strengths of recycled aggregate concrete at 7 and 14 days were normalized by the corresponding 28-day strength. The results are shown in Figure 8. The following logarithmic relationship between the normalized compressive strength and age of concrete is proposed.

$$
\frac{f_{c}^{\prime}(t)}{f_{c}^{\prime}}=0.1758 \ln t+0.423
$$

Where $f_{c}^{\prime}(t)=$ compressive strength (MPa) at age $t$ days and $f_{c}^{\prime}=$ compressive strength (MPa) at 28 days. From this relationship, 28 days strength can be obtained from 3 days or 7 days or 14 days known strength.

\section{Relationship between Compressive Strength and UPV}

The variation of compressive strength of concrete with Ultrasonic Pulse Velocity (UPV) is shown in Figure 9. The following exponential relationship is proposed between compressive strength and UPV.

$$
f_{c}^{\prime}=1.5757 e^{0.0007 U P V}
$$

Where $f_{c}^{\prime}=$ compressive strength of concrete (MPa) and $U P V=$ Ultrasonic pulse velocity $(\mathrm{m} / \mathrm{sec})$. The author conducted a study on ultrasonic pulse velocity through concrete made with virgin brick aggregate. The results summarized separately (Mohammed and Mahmood 2016). Comparing the results with this study, it is found that for the same size of aggregate, for similar strength of concrete, the pulse velocity is slower for concrete made with recycled aggregate.

\section{Stress-Strain Relationship}

The variation of normalized stress (normalized stress $=$ particular stress divided by compressive strength of concrete) with strain of concrete made with recycled brick aggregate is shown in Figure 10. The following nonlinear relationship is proposed between stress and strain of concrete made with recycled brick aggregate. 


$$
\frac{f_{c}}{f_{c}^{\prime}}=\frac{1.46197 \epsilon}{0.000834+\varepsilon}
$$

Where $\frac{f_{c}}{f_{c}^{\prime}}=$ normalized stress, and $\mathrm{e}=$ strain of concrete.

\section{Statistical Analysis of Data for Compressive Strength}

Using normal distribution, the PDF and CDF functions of 28-day compressive strength of concrete made with recycled brick aggregates collected from 6 different sites were drawn as shown in Figure 11 for $\mathrm{W} / \mathrm{C}=0.55$ and $\mathrm{W} / \mathrm{C}=0.45$. The average strength for $\mathrm{W} / \mathrm{C}=0.55$ was $23.5 \mathrm{MPa}$ and the same for $\mathrm{W} / \mathrm{C}=0.45$ was $29 \mathrm{MPa}$. The ten percentile values of 28-day compressive strength of concrete were $17 \mathrm{MPa}$ and $26 \mathrm{MPa}$ for $\mathrm{W} / \mathrm{C}=0.55$ and $\mathrm{W} / \mathrm{C}=0.45$ respectively.

\section{FURTHER INVESTIGATIONS}

A report on physical properties of recycled brick aggregate and mechanical properties of concrete made with recycled brick aggregate was summarized earlier based on the results of an extensive investigation conducted on recycled brick aggregate collected from 33 demolished building sites [Mohammed et al 2015]. For the development of an accurate and complete guideline for recycling of brick aggregate as coarse aggregate, a decision was made to increase the population of number of sites from 33 to 50 . Therefore, this extended study was conducted by using aggregates collected from six different demolished building sites. In the near future, the same study will be continued for additional eleven demolished building sites. Summarizing all data of 50 different demolished building sites, it will be possible to make a complete and a strong platform for recycling of demolished concrete made with brick aggregate. The results are expected to summarize by 2020 .

\section{CONCLUSIONS}

From the scope of this investigation on recycling of brick aggregate concrete, the following conclusions are drawn:

1. Compared to the virgin brick aggregate, the recycled brick aggregates show lower absorption capacity;

2. The workability of recycled aggregate concrete is higher than first class brick aggregate;

3. For $\mathrm{W} / \mathrm{C}=0.55$, the recycled aggregate concrete gives lower strength compared to the virgin brick aggregate. However, if W/C is reduced (from 0.55 to 0.45 ), the strength and Young's modulus of concrete are improved significantly;

4. The average strength of recycled aggregate concrete is found to be $29.0 \mathrm{MPa}$ and 23.5 MPa for $\mathrm{W} / \mathrm{C}=0.45$ and 0.55 , respectively. 


\section{REFERENCES}

Alan, D. B. (1997). "Recycled Concrete as a Source of Aggregate." ACI Journal, American Concrete Institute, 212-219.

Gomez-Soberon, J. M., Gomez-Soberon, J. C., Gomez-Soberon, L. A. (2002). "Shrinkage and Creep of Recycled Concrete Interpreted by the Porosity of the Aggregate." Sustainable Concrete Construction, Ed. Dhir, R. K., Dyer, T. D., Halliday, J. E., in Proceedings of the International Conference, University of Dundee, Scotland, UK, 563-575.

Mehta, P. K. (2002). "Greening of the Concrete Industry for the Sustainable Development." ACI Concrete International, 24 (7), 23-28.

Torring, M., Lauritzen, E. (2002). "Total Recycling Opportunities - Tasting the Topics for the Conference Session." Sustainable Concrete Construction, Ed. Dhir, R. K., Dyer, T. D., Halliday, J. E., in Proceedings of the International Conference, University of Dundee, Scotland, UK, 501-510.

Yanagibashi, K., Yonezawa, T., Arakawa, K., Yamada, M. (2002). "A New Concrete Recycling Technique for Coarse Aggregate Regeneration Process." Sustainable Concrete Construction, Ed. Dhir, R. K., Dyer, T. D., Halliday, J. E., in Proceedings of the International Conference, University of Dundee, Scotland, UK, 511-52.

Mohammed, T. U. (2007). "Bangladesh - Sustainable Development of Concrete Technology." Proceedings of the CBM-CI-International Workshop, Ed. Ahmad, S., Karachi, Pakistan, 249-267.

Mohammed, T. U., Hasnat A., Awal M. A., Bosunia, S. Z. (2015). "Recycling of brick aggregate concrete as coarse aggregate." Journal of Materials in Civil Engineering, ASCE, 27(7), Paper No. B4014005.

Mohammed, T. U., Mahmood, A. H., (2016). "Effect of Maximum Aggregate Size on UPV of Brick Aggregate Concrete", Journal of Ultrasonics, Vol. 69, pp. 129-136, doi:10.1016/j.ultras.2016.04.006. 